University of Nebraska - Lincoln

DigitalCommons@University of Nebraska - Lincoln

Faculty Papers and Publications in Animal

Science

Animal Science Department

August 1965

\title{
Genetic Covariances among Relatives for Dairy Lactation Records
}

L. Dale Van Vleck

University of Nebraska-Lincoln, dvan-vleck1@unl.edu

G. E. Bradford

Cornell University

Follow this and additional works at: https://digitalcommons.unl.edu/animalscifacpub

Part of the Animal Sciences Commons

Van Vleck, L. Dale and Bradford, G. E., "Genetic Covariances among Relatives for Dairy Lactation Records" (1965). Faculty Papers and Publications in Animal Science. 172.

https://digitalcommons.unl.edu/animalscifacpub/172

This Article is brought to you for free and open access by the Animal Science Department at DigitalCommons@University of Nebraska - Lincoln. It has been accepted for inclusion in Faculty Papers and Publications in Animal Science by an authorized administrator of DigitalCommons@University of Nebraska - Lincoln. 
Published in Genetics 52: 385-390 (August 1965).

Copyright (c) Genetic Society of America.

Full text available online at:

http://www.genetics.org/cgi/reprint/52/2/385

\title{
Genetic Covariances among Relatives for Dairy Lactation Records
}

\author{
L. D. Van Vleck and G. E. Bradford \\ Department of Animal Husbandry, Cornell University, Ithaca, New York
}

Submitted April 2, 1965

\section{SUMMARY}

Trios of first lactation records of a cow, her dam, and her granddam were analyzed in an attempt to distinguish between additive by additive genetic effects and maternal genetic effects as possible explanations of much higher heritability estimates from daughterdam regression than from paternal half-sib correlations. The results based on first lactation records expressed as deviations from herdmate averages suggest that additive by additive effects, and probably environmental correlation contribute little or nothing to covariance between daughter and dam records. Genetic maternal effects may account for about $20 \%$ and direct additive genetic effects for $23 \%$ of within-herd variance for first lactation records expressed as deviations. The method of using deviations, however, may cause an automatic environmental correlation between the daughter and dam records. Other evidence, however, suggests that this might not be an important reason for the increase in daughter-dam covariance for deviations. Analyses of mature equivalent records of artificially sired cows, however, gave the conflicting impression that genetic maternal effects were not important and that additive genetic variance accounted for about $4.0 \%$ of the within herd variance. Confounding of year and sire effects, however, may have caused the increase in four times the paternal half-sib correlation to the same magnitude as twice the daughter-dam regression. 